AT - TADBIR

JURNAL ILMIAH MANAJEMEN

\title{
Pengaruh Motivasi Kerja Dan Kompetensi Terhadap Kinerja Karyawan Yayasan Bina Insan Nusantara Barito Di Buntok, Provinsi Kalimantan Tengah
}

\author{
Agustina Muliyani \\ Program Manajemen, Sekolah Tinggi Ilmu Ekonomi Dahani Dahanai \\ Jl. Cut Nyak Dien, Buntok - Kalimantan Tengah \\ email : agus_muliyani@yahoo.co.id
}

\begin{abstract}
Human Resources is an investment that must exist and an absolute condition for the organization's operations. The purpose of this study was to determine the extent of work motivation and competence partially significant effect on the performance of Bina Insan Nusantara Barito Foundation employees in Buntok. The results of testing Hypothesis 1 (H1) using Path Coefficens indicate that there is a positive influence on the variable of Work Motivation (XI) on Employee Performance (Y). This is obtained from the sample orginal value of 0.415 with a t-statistic value of 2.966 which is greater than the t-table value (1.96). These results prove that work motivation partially has a positive and significant effect on employee performance. Testing hypothesis 2 (H2) using Path Coefficens shows that there is a positive influence on the Competency variable (X2) on Employee Performance (Y). This is obtained from the sample orginal value of 0.397 with a $t$-statistic value of 2.523 which is greater than the t-table value (1.96). These results prove that competence has a positive and significant effect on employee performance. Thus answered the hypothesis of the research Effect of Work Motivation and Competence on Employee Performance of the Bina Insan Nusantara Barito Foundation in Buntok, Central Kalimantan Province. Bina Insan Nusantara Barito Foundation needs to work towards improving welfare. The spirit of the performance of the teachers at the foundation to be maintained, given that it is exceedingly difficult to find teachers who have dedication and have high work loyalty.
\end{abstract}

Keywords: work motivation, employee competence and performance

\begin{abstract}
Abstrak
Sumber Daya Manusia merupakan investasi yang harus ada dan syarat mutlak berlangsungnya operasi organisasi. Tujuan penelitian ini adalah untuk mengetahui sejauhmana motivasi kerja dan kompetensi secara parsial berpengaruh signifikan terhadap kinerja karyawan Yayasan Bina Insan Nusantara Barito di Buntok. Hasil Pengujian hipotesis 1 (H1) dengan menggunakan Path Coefficens menunjukkan bahwa terdapat pengaruh positif variabel Motivasi Kerja (X1) terhadap Kinerja Karyawan (Y). Hal ini diperoleh dari nilai orginal sample sebesar 0,415 dengan nilai t-statistik 2,966 nilai tersebut lebih besar dari nilai ttabel $(1,96)$. Hasil ini membuktikan bahwa Motivasi Kerja secara parsial berpengaruh positif dan signifikan terhadap Kinerja Karyawan. Pengujian hipotesis 2 (H2) dengan menggunakan Path Coefficens menunjukkan bahwa terdapat pengaruh positif variabel Kompetensi (X2) terhadap Kinerja Karyawan (Y). Hal ini diperoleh dari nilai orginal sample sebesar 0,397 dengan nilai t-statistik 2,523 nilai tersebut lebih besar dari nilai t-tabel $(1,96)$. Hasil ini membuktikan bahwa Kompetensi berpengaruh positif dan signifikan terhadap Kinerja Karyawan. Dengan demikian terjawab hipotesis dari penelitian Pengaruh Motivasi Kerja dan Kompetensi terhadap Kinerja Karyawan Yayasan Bina Insan Nusantara Barito di Buntok, Provinsi Kalimantan Tengah. Yayasan Bina Insan Nusantara Barito perlu mengupayakan peningkatan kesejahteraan. Semangat dari kinerja guru-guru di yayasan agar terus dipertahankan, mengingat sangat susah mencari guru-guru yang memiliki dedikasi dan memiliki loyalitas kerja yang tinggi.
\end{abstract}

Kata kunci : motivasi kerja, kompetensi dan kinerja karyawan 


\section{PENDAHULUAN}

Menurut Wirawan (2008: 1) sumber daya merupakan sumber energi, tenaga, kekuatan (power) yang diperlukan untuk menciptakan daya, gerak, aktivitas, kegiatan dan tindakan. Sumber daya tersebut antara lain terdiri atas sumber daya alam, sumber daya finansial, sumber daya manusia, sumber daya ilmu pengetahuan dan sumber daya teknologi. Diantara sumber daya tersebut, sumber daya yang terpenting adalah sumber daya manusia (SDM - human resources). Sumber Daya Manusia merupakan sumber daya yang digunakan untuk menggerakkan dan menyinergikan sumber daya lainnya untuk mencapai tujuan organisasi. Tanpa Sumber Daya Manusia, sumber daya lainnya menganggur (idle) dan kurang bermanfaat dalam mencapai tujuan organisasi.

Dalam proses pembelajaran tentu ada kegagalan dan keberhasilannya. Kegagalan karyawan dalam melaksanakan tugas tidak sepenuhnya berasal dari diri karyawan tersebut tetapi bisa juga dari organisasi tidak berhasil dalam memberikan motivasi yang mampu membangkitkan semangat karyawan dalam bekerja. Keberhasilan kerja karyawan tidak lepas dari motivasi karyawan yang bersangkutan. Oleh karena itu pada dasarnya motivasi kerja merupakan faktor yang sangat menentukan keberhasilan karyawan dalam melaksanakan tugas yang dibebankan organisasi kepadanya. Karyawan juga akan lebih termotivasi jika dari hasil kerjanya tersebut mendapatkan kompensasi yang memuaskan dari organisasi sebagai tanda penghargaan atas hasil kerjanya tersebut.

Selain motivasi karyawan juga memerlukan kompetensi. Dalam dunia kerja semakin tinggi kompetensi seseorang maka semakin tinggi nilai jual orang tersebut, termasuk jika ini dihubungkan dengan nilai finansial, atau dengan kata lain perolehan finansial yang bisa diperoleh akan semakin tinggi. Untuk memperoleh risiko kompetensi tersebut maka ia dituntut untuk melakukan pengembangan diri baik dari segi education (pendidikan) maupun pengalaman yang semua ini sering disebut dengan pembelajaran.

Organisasi yang profesional tidak akan mampu mewujudkan suatu manajemen kinerja yang baik tanpa ada dukungan yang kuat dari seluruh komponen manajemen perusahaan dan juga tentunya para pemegang saham. Motif berprestasi yang perlu dimiliki oleh pegawai harus ditumbuhkan dari dalam diri sendiri selain dari lingkungan kerja. Hal ini karena motif berprestasi yang ditumbuhkan dari dalam diri sendiri akan membentuk suatu kekuatan diri dan jika situasi lingkungan kerja turut menunjang maka pencapaian kinerja akan lebih mudah. Organisasi tentu tidak bisa lepas dari karyawan, dengan perkembangan teknologi yang pesat kadang-kadang mereka lebih cepat tahu tentang bentuk kehidupan yang jauh disana maupun sekitarnya. Adanya ketergantungan satu sama lain membuat kita perlu menghargai karya orang lain.

Yayasan Bina Insan Nusantara Barito adalah Lembaga Pendidikan yang berbadan hukum, menyelenggarakan pendidikan sebagai bentuk partisipasi dalam rangka mencerdaskan kehidupan bangsa Indonesia. Yayasan Bina Insan Nusantara Barito menyelenggarakan pendidikan dari PAUD, TK dan TPA (Tempat Penitipan Anak), yang lembaga pendidikannya dinamakan PAUD Play Group-Buntok English Kids, TK Bina Nusantara dan Tempat Penitipan Anak Buntok English Kids. Yayasan ini terletak di J1. Pelita Raya, Gg. Sempurna, Buntok, Kecamatan Dusun Selatan, Kabupaten Barito Selatan, Provinsi Kalimantan Tengah. Jumlah karyawan yang ada di Yayasan Bina Insan Nusantara Barito, sebanyak 32 orang guru.

Yayasan Bina Insan Nusantara Barito 
bergerak di bidang pendidikan ini tetap mengemban visi dan misi pendiri yang direalisasikan dalam visi dan misi Yayasan. Dengan berpedoman pada visi dan misi pendiri yang nota benenya adalah menyiapkan generasi kedepan, menjadi manusia Indonesia yang cerdas, sehat, ceria, berkarakter dan berakhlak mulia, maka tujuan dari lembaga pendidikan tersebut tidak semata-mata untuk mencari profit tetapi memberikan kesempatan kepada setiap anak yang masih berusia dini agar dapat tumbuh dan berkembang secara optimal sesuai dengan tingkat usianya, perkembangan, psikologisnya, potensi dan minat serta bakatnya dan juga kebutuhan spesifikasinya.

Fenomena yang terjadi menunjukkan belum optimalnya motivasi dan kompetensi pada Yayasan Bina Insan Nusantara Barito, diantaranya :

- Yayasan belum dapat memberikan kenyaman kerja pada setiap guru

- Yayasan kurang memberikan penghargaan kepada guru yang memiliki loyalitas dan etos kerja yang tinggi.

- Guru-guru belum menerapkan ilmu yang diperoleh ketika mengikuti pelatihan, guna kemajuan yayasan

- Belum adanya keterbukaan dari pihak yayasan kepada guru-guru mengenai kondisi keuangan Yayasan. Karena dana yang ada pada saat ini digunakan oleh yayasan untuk pembangunan gedung dan penambahan fasilitas guna menunjang sarana belajar mengajar.

Namun ada hal yang membuat peneliti merasa bahwa guru-guru tersebut adalah orang-orang yang luar biasa. Walaupun ada beberapa indikator pada motivasi kerja dan kompetensi yang masih lemah, akan tetapi untuk indikator kinerja pegawainya sangat memuaskan. Hal ini dikarenakan guru-guru memiliki dedikasi dan loyalitas kerja yang sangat tinggi, mereka yang sungguh-sungguh terpanggil untuk terlibat dalam mempersiapkan generasi muda dan dengan rela menerima kompensasi yang hanya dapat memenuhi kebutuhan mereka, artinya kompensasi yang diberikan belum sesuai dengan ketentuan umum yang berlaku (aturan gaji pegawai negri sipil atau upah minimum regional) tetapi sesuai dengan kemampuan Yayasan.

Itulah yang membuat saya semakin bersemangat untuk mengangkat hal ini agar menjadi bahan pembelajaran yang sangat bermanfaat bagi kita semua dan menjadi bahan masukan dan evaluasi bagi pihak Yayasan pada khususnya.

Berdasarkan uraian diatas dapat dikemukakan permasalahannya adalah sebagai berikut : apakah motivasi kerja secara parsial berpengaruh signifikan terhadap kinerja karyawan Yayasan Bina Insan Nusantara Barito di Buntok? dan apakah kompetensi secara parsial berpengaruh signifikan terhadap kinerja karyawan Yayasan Bina Insan Nusantara Barito di Buntok?

\section{KAJIAN PUSTAKA}

\section{Motivasi Kerja}

Untuk mempermudah pemahaman motivasi kerja, dibawah ini dikemukakan pengertian motif, motivasi dan motivasi kerja. Abraham Sperling

(1987:183) mengemukakan bahwa motif didefinisikan sebagai suatu kecenderungan untuk beraktivitas, dimulai dari dorongan dalam diri dan diakhiri dengan penyesuaian diri. Penyesuaian diri dikatakan untuk memuaskan motif.

William J. Stanton (1981:101) mendefinisikan bahwa motif adalah kebutuhan yang distimulasi yang berorientasi kepada tujuan individu dalam mencapai rasa puas. Fillmore H. Stanford (1969:173) mendefinsikan motivasi sebagai suatu kondisi yang menggerakkan manusia kearah suatu tujuan tertentu.

Menurut Arif Yusuf Hamali (2018:130), 
istilah motivasi (motivation) berasal dari bahasa Latin, yaitu "movere" yang artinya "menggerakkan" (to move). Gray (dalam Winardi, 2011 : 2) mendefinisikan motivasi sebagai hasil sejumlah proses yang bersifat internal atau eksternal bagi seorang individu, yang menyebabkan timbulnya sikap antusias dan persistence dalam hal melaksanakan kegiatan-kegiatan tertentu. Rumusan definisi tersebut menanggapi perbincangan yang berlangsung dalam bidang riset motivasional, tentang mengapa seseorang dapat bersikap antusias dan persistence dalam hal melaksanakan tugas. Salah satu pandangan mengatakan bahwa kebutuhan-kebutuhan yang tidak dapat diobservasi (kebutuhan internal) memotivasi perilaku.

Berdasarkan pendapat para ahli diatas, dapat disimpulkan bahwa motif merupakan suatu dorongan kebutuhan dalam diri pegawai yang perlu dipenuhi agar pegawai tersebut dapat menyesuaikan diri terhadap lingkungannya. Motivasi adalah kondisi yang menggerakkan pegawai agar mampu mencapai tujuan dari motifnya. Sedangkan, motivasi kerja yang dikemukakan oleh Ernest J. Mc Cormick (1985:268) motivasi kerja adalah kondisi yang berpengaruh membangkitkan, mengarahkan dan memelihara perilaku yang berhubungan dengan lingkungan kerja. (Mangkunegara, 2001:93-94).

Seseorang yang termotivasi, yaitu orang yang melaksanakan upaya substansial guna menunjang tujuan-tujuan produksi kesatuan kerjanya dan organisasi tempat seseorang bekerja. Seseorang yang tidak termotivasi hanya memberikan upaya minimum dalam hal bekerja. Konsep motivasi merupakan sebuah konsep penting dalam studi tentang kinerja kerja individual. Motivasi merupakan sebuah determinan penting bagi kinerja individual. Motivasi bukan satu-satunya determinan karena masih ada variabel-variabel yang turut mempengaruhinya, seperti : upaya (kerja) yang dikerahkan, kemampuan orang yang bersangkutan dan pengalaman (kerja) sebelumnya. Motivasi memiliki arti penting bagi suatu organisasi atau perusahan sebagai berikut : tingkat kinerja yang tinggi, keinginan keluar dan ketidahadiran karyawan yang rendah, penerimaan perubahan organisasi, serta gambaran organisasi.

Mangkunegara (2007:90-94), dalam teori Abraham Maslow mengemukakan bahwa hierarki kebutuhan manusia adalah sebagai berikut :

1) Kebutuhan fisiologis yaitu kebutuhan untuk makan, minum, perlindungan fisik, bernapas, seksual. Kebutuhan ini merupakan kebutuhan tingkat terendah atau disebut pula sebagai kebutuhan yang paling dasar

2) Kebutuhan rasa aman yaitu kebutuhan akan perlindungan dari ancaman, bahaya, pertentangan dan lingkungan kerja.

3) Kebutuhan untuk merasa memiliki yaitu kebutuhan untuk diterima oleh kelompok, berafiliasi, berinteraksi, dan kebutuhan untuk mencintai serta dicintai.

4) Kebutuhan akan harga diri, yaitu kebutuhan untuk dihormati, dan dihargai oleh orang lain.

5) Kebutuhan untuk mengaktualisasikan diri, yaitu kebutuhan untuk menggunakan kemampuan, skill, dan potensi. Kebutuhan untuk berpendapat dengan mengemukakan ide-ide memberi penilaian dan kritik terhadap sesuatu.

Abraham Maslow mengemukakan bahwa orang dewasa secara normal memuaskan kirakira $85 \%$ kebutuhan fisiologis, $70 \%$ kebutuhan rasa aman, 50\% kebutuhan untuk memiliki dan mencintai, $40 \%$ kebutuhan harga diri dan hanya $10 \%$ kebutuhan aktualisasi diri.

$\begin{array}{cccr}\text { Sedangkan } & \text { David } & \text { Mc } & \text { Clelland } \\ \text { mengemukakan } & \text { adanya } & \text { tiga } & \text { macam }\end{array}$


kebutuhan manusia, yaitu sebagai berikut :

a) Need for achievement, yaitu kebutuhan untuk berprestasi yang merupakan refleksi dari dorongan akan tanggung jawab untuk pemecahan masalah. Seorang karyawan yang mempunyai kebutuhan akan berprestasi tinggi cenderung untuk berani mengambil risiko. Kebutuhan untuk berprestasi adalah kebutuhan untuk melakukan pekerjaan lebih baik daripada sebelumnya, selalu berkeinginan mencapai prestasi yang lebih tinggi.

b) Need for affiliation, yaitu kebutuhan untuk berafiliasi yang merupakan dorongan untuk berinteraksi dengan orang lain, berada bersama orang lain, tidak mau melakukan sesuatu yang merugikan orang lain.

c) Need for power, yaitu kebutuhan untuk kekuasaan yang merupakan refleksi dari dorongan untuk mencapai rutinitas untuk memiliki pengaruh terhadap orang lain.

Terdapat beberapa prinsip dalam memotivasi kerja pegawai yaitu sebagai berikut : prinsip partisipasi, prinsip komunikasi, prinsip mengakui andil bawahan, prinsip pendelegasian wewenang dan prinsip memberikan perhatian.

Anwar Prabu Mangkunegara (2007:101102) mengemukakan teknik-teknik memotivasi kerja karyawan antara lain : teknik pemenuhan kebutuhan karyawan dan teknik komunikasi persuasif.

\section{Kompetensi}

Menurut Irham (2015:52-57) Kompetensi adalah suatu kemampuan yang dimiliki oleh seorang individu yang memiliki nilai jual dan itu teraplikasi dari hasil kreativitas serta inovasi yang dihasilkan. Sedangkan menurut Boulder, kompetensi adalah karakteristik dasar dari seseorang yang memungkinkan mereka mengeluarkan kinerja superior dalam pekerjaannya, (Boulder et.al, 1996). Dalam dunia kerja semakin tinggi kompetensi seseorang maka semakin tinggi nilai jual orang tersebut, termasuk jika ini dihubungkan dengan nilai finansial, atau dengan kata lainnya perolehan finansial yang bisa diperoleh akan semakin tinggi. Untuk memperoleh nilai kompetensi tersebut maka ia dituntut untuk melakukan pengalaman yang semua ini sering disebut dengan pembelajaran

Adapun jenis-jenis kompetensi ada tiga macam yaitu sebagai berikut : kompetensi organisasi, kompetensi pekerjaan atau teknis, dan kompetensi individual. Karakteristik yang mendasari kompetensi adalah sebagai berikut : motif, traits, konsep diri, penge-tahuan, dan skill.

Efektivitas kerja seorang karyawan akan terlihat dari kinerja yang dihasilkan. Kompetensi didefinisikan sebagai aspekaspek pribadi dari seorang pekerja yang memungkinkan untuk mencapai kinerja yang superior. Aspek-aspek pribadi ini mencakup sifat, motif-motif, sistem nilai, sikap, pengetahuan dan keterampilan dimana kompetensi akan mengarahkan tingkah laku, sedangkan tingkah laku akan menghasilkan kinerja (Lasmahadi, 2002).

Kompetensi tidak bisa dilepaskan dengan kecakapan. Karena kecakapan menggambarkan kompetensi seseorang, dengan kata lain semakin tinggi kecakapan seseorang maka semakin tinggi kompetensi seseorang. Memang kecakapan bisa dibangunkan dan termiliki asal karyawan tersebut dengan sungguh-sungguh serta konsisten dalam usaha membangun kompetensi yang diinginkannya.

Untuk membangun kecakapan kompetensi seseorang sangat dipengaruhi oleh berbagai faktor pendukung, dan seorang karyawan sebaiknya harus memperhatikan apa saja yang menjadi faktor pendukung terwujudnya kecakapan tersebut. Faktor yang dapat memengaruhi kecakapan kompetensi seseorang yaitu : keyakinan dan nilai-nilai; keterampilan; karakteristik kepribadian; 
motivasi; isu emosional; kemampuan intelektual; dan budaya organisasi

\section{Kinerja Karyawan}

Menurut Irham (2015:176), Kinerja adalah hasil yang diperoleh oleh suatu organisasi baik organisasi tersebut bersifat profit oriented dan non profit oriented yang dihasilkan selama satu periode waktu. Sedangkan menurut Anwar Prabu Mangkunegara (2001:67-68) istilah kinerja berasal dari kata job performance atau actual performance (prestasi kerja atau persetasi sesungguhnya yang dicapai oleh seseorang). Kinerja (prestasi kerja) adalah hasil kerja secara kualitas dan kuantitas yang dicapai oleh seorang pegawai dalam melaksanakan tugasnya sesuai dengan tanggung jawab yang diberikan kepadanya. Menurut Wirawan (2008:5) Kinerja adalah keluaran yang dihasilkan oleh fungsi-fungsi atau indikatorindikator suatu pekerjaan atau suatu profesi dalam waktu tertentu.

Untuk mengukur variabel kinerja karyawan, maka diperlukan indikator sebagai berikut : kualitatif (seberapa baik); ketepatan waktu menyelesaikan tugas; efektivitas penggunaan sumber organisasi; dan cara melakukan pekerjaan.

\section{METODE PENELITIAN}

Dalam Penelitian ini, desain yang digunakan adalah desain deskriptif kuantitatif, yaitu dengan cara mengolah data menggunakan Analisis Partial Least Square atau yang biasa disingkat PLS. Menurut Imam Ghozali (2008 : 30-35) Partial Lease Square (PLS) merupakan metode analisis yang powerful karena tidak mengasumsikan data harus dengan pengukuran skala tertentu, jumlah sampel kecil. Menggunakan metode ini karena populasi dan sampel hanya 32 orang responden.
Sampel adalah bagian dari jumlah dan karakteristik yang dimiliki oleh populasi tersebut (Sugiyono, 1999 : 72). Sampel dalam penelitian ini adalah Guru pada Yayasan Bina Insan Nusantara Barito yang berlokasi di Buntok berjumlah 32 orang. Teknik pengambilan sampel yang digunakan adalah sampling jenuh. Sampling jenuh adalah teknik penentuan sampel bila semua anggota populasi digunakan sebagai sampel. Istilah lain sampel jenuh adalah sensus, dimana semua anggota populasi dijadikan sampel. (Dr. Sugiyono, 1999 : 78). Sedangkan teknik pengumpulan data meng-gunakan observasi, kuesioner, wawancara dan dokumentasi.

\section{Pengukuran Variabel}

Untuk mempermudah melakukan pengukuran atas variabel-variabel tersebut maka penulis mengambil beberapa indikator. Adapun indikator-indikator terpilih dilihat pada tabel 1 .

\section{HASIL DAN PEMBAHASAN}

Hasil

Dalam menganalisis dengan menggunakan metode PLS terdapat dua tahap analisis dimana tahap pertama adalah menganalisa validitas dan reliabilitas model. Sedangkan tahap kedua adalah tahap pengukuran model hubungan variabel dengan konstruk (Outer Model) dan juga analisa jalur antar variabel (Inner Model).

\section{Uji Validitas Dan Reliabilitas Konstruk Validitas Konvergen}

Convergent Validity adalah pengujian outer model untuk setiap variabel laten yang menggunakan indikator reflektif untuk mengetahui validitas indikator konstruk/ variabel laten dari model penelitian. Indikator konstruk/variabel laten dianggap valid jika memiliki nilai outer loading di atas 0,5 dan atau nilai t-statistik di atas 1,96. Hasil 
pengujian validitas konvergen secara lengkap disajikan pada Tabel 2.

Tabel 1. Pengukuran Variabel

\begin{tabular}{|c|c|c|c|}
\hline Variabel & Indikator & Item & Sumber \\
\hline $\begin{array}{l}\text { Motivasi } \\
\text { Kerja (X1) }\end{array}$ & $\begin{array}{ll}\text { X1.1 } & \text { Fisiologis } \\
\text { X1.3 } & \text { Kebutuhan sosial / merasa memiliki }\end{array}$ & $\begin{array}{l}\mathrm{X} 1.1 .1 \\
\mathrm{X} 1.3 .1\end{array}$ & $\begin{array}{c}\text { Abraham Maslow } \\
\text { Anwar Prabu, } \\
\text { (2001:81-94) }\end{array}$ \\
\hline $\begin{array}{l}\text { Kompetensi } \\
\quad(\mathrm{X} 2)\end{array}$ & $\begin{array}{ll}\text { X2.1 } & \text { Pengetahuan } \\
\text { X2.2 } & \text { Keterampilan } \\
\text { X2.3 } & \text { Perilaku }\end{array}$ & $\begin{array}{l}\mathrm{X} 2.1 .1 \\
\mathrm{X} 2.2 .1 \\
\mathrm{X} 2.3 .1\end{array}$ & $\begin{array}{l}\text { Wirawan } \\
(2008: 9)\end{array}$ \\
\hline $\begin{array}{l}\text { Kinerja } \\
\text { karyawan } \\
\text { (Y) }\end{array}$ & $\begin{array}{ll}\text { Y1 } & \text { Kualitatif (seberapa baik) } \\
\text { Y2 } & \text { Ketepatan waktu menyelesaikan tugas } \\
\text { Y3 } & \text { Efektivitas penggunaan sumber } \\
& \text { organisasi } \\
\text { Y4 } & \text { Cara melakukan pekerjaan }\end{array}$ & $\begin{array}{l}\text { Y1.1 } \\
\text { Y2.1 } \\
\text { Y3.1 } \\
\text { Y4.1 }\end{array}$ & $\begin{array}{c}\text { Wirawan } \\
(2008: 69-71)\end{array}$ \\
\hline
\end{tabular}

Sumber : data primer diolah : 2020

Tabel 2. Hasil pengujian convergent validity.

\begin{tabular}{|c|c|c|c|c|}
\hline \multirow{2}{*}{ Variabel } & Item & Outer Loadings & $\begin{array}{c}\text { Nilai } \\
\text { t-statistik }\end{array}$ & Kesimpulan (t- >1,96) \\
\hline \multirow{2}{*}{ Motivasi Kerja (X1) } & X1.1 & 0,692 & 2,681 & Valid \\
\cline { 2 - 5 } & X1.3 & 0,933 & 15,088 & Valid \\
\hline \multirow{3}{*}{ Kompetensi (X2) } & X2.1 & 0,729 & 3,423 & Valid \\
\cline { 2 - 5 } & X2.2 & 0,839 & 10,191 & Valid \\
\cline { 2 - 5 } & X2.3 & 0,737 & 6,762 & Valid \\
\hline \multirow{3}{*}{ Kinerja Karyawan (Y) } & Y1 & 0,781 & 5,580 & Valid \\
\cline { 2 - 5 } & Y2 & 0,880 & 10,185 & Valid \\
\cline { 2 - 5 } & Y3 & 0,873 & 12,827 & Valid \\
\cline { 2 - 5 } & Y4 & 0,649 & 3,858 & Valid \\
\hline
\end{tabular}

Sumber : data primer diolah : 2020

Tabel 3. Nilai cross loading pengujian discriminant validity

\begin{tabular}{|c|c|c|c|}
\hline Item & Motivasi Kerja (X1) & Kompetensi (X2) & Kinerja Karyawan (Y) \\
\hline X1.1 & $\mathbf{0 , 6 9 2}$ & 0,463 & 0,350 \\
X1.3 & $\mathbf{0 , 9 3 3}$ & 0,641 & 0,702 \\
\hline X2.1 & 0,494 & $\mathbf{0 , 7 2 9}$ & 0,415 \\
X2.2 & 0,719 & $\mathbf{0 , 8 3 9}$ & 0,609 \\
X2.3 & 0,335 & $\mathbf{0 , 7 3 7}$ & 0,520 \\
\hline Y1 & 0,414 & 0,488 & $\mathbf{0 , 7 8 1}$ \\
Y2 & 0,600 & 0,566 & $\mathbf{0 , 8 8 0}$ \\
Y3 & 0,722 & 0,519 & $\mathbf{0 , 8 7 3}$ \\
Y4 & 0,406 & 0,608 & $\mathbf{0 , 6 4 9}$ \\
\hline
\end{tabular}

Sumber : data primer diolah, 2020 


\begin{tabular}{|c|c|c|c|}
\hline Kode & Indikator & Skor mean & Variable mean \\
\hline $\mathrm{X} 1.1$ & Fisiologis & 3,28 & \multirow{2}{*}{3,59} \\
\hline $\mathrm{X} 1.3$ & Kebutuhan sosial / merasa memiliki & 3,91 & \\
\hline $\mathrm{X} 2.1$ & Pengetahuan & 4,03 & \multirow{3}{*}{4,01} \\
\hline $\mathrm{X} 2.2$ & Keterampilan & 4,00 & \\
\hline $\mathrm{X} 2.3$ & Perilaku & 4,00 & \\
\hline Y1 & Kualitatif (seberapa baik) & 4,16 & \multirow{4}{*}{4,05} \\
\hline Y2 & Ketepatan waktu menyelesaikan tugas & 3,91 & \\
\hline Y3 & Efektivitas penggunaan sumber organisasi & 4,03 & \\
\hline Y4 & Cara melakukan pekerjaan & 4,09 & \\
\hline
\end{tabular}

Sumber: Data diolah, 2020

Pengujian Convergent Validity, pada 2 diatas hasilnya telah menunjukkan bahwa nilai t-statistik lebih besar dari nilai t-tabel $(1,96)$ dan tidak ada outer loading yang nilainya di bawah 0,5 , sehingga dapat disimpulkan bahwa semua indikator variabel laten (konstruk) pengukuran ini memenuhi persyaratan validitas konvergen.

\section{Validitas Diskriminan}

Pengujian Discriminant Validity pada indikator reflektif untuk mengetahui indikasi variabel laten (konstruk) dalam memprediksi indikatornya sendiri lebih baik daripada indikator konstruk/variabel laten yang lain. Untuk pengujian dicriminant validity diperoleh dari nilai cross loading, yakni nilai korelasi indikator terhadap konstruk/variabelnya seharusnya lebih besar dibandingkan dari nilai korelasi antar indikator dengan konstruk/variabel yang lain. Hasil pengujian discriminant Validity disajikan pada tabel 3 .

Pada tabel 3 tersebut di atas hasil cross loading menunjukkan bahwa nilai korelasi variabel motivasi kerja dengan indikatornya lebih tinggi dibandingkan dengan nilai korelasi indikator variabel kompetensi dan kinerja karyawan. Demikian juga berlaku sebaliknya. Hal ini menunjukkan bahwa variabel laten memprediksi indikator pada bloknya lebih baik dibandingkan dengan indikator di blok lainnya. Berdasarkan hasil analisis tersebut, dapat disimpulkan bahwa telah memenuhi discriminant validity.

Selain itu, untuk menguji discriminant validity adalah melihat nilai akar Average Variance Extracted (AVE) untuk setiap variabel laten dan membandingkannya dengan korelasi antar variabel laten yang dapat dilihat pada tabel 4.

Berdasarkan tabel 4 tersebut di atas hasil akar average variance extracted (AVE) menunjukkan nilai yang lebih besar daripada nilai korelasi antar variabel latennya (correlations of the latent variables), sehingga dengan demikian dapat disimpulkan bahwa semua konstruk/variabel laten memenuhi kriteria validitas diskriminan.

Tabel 4. Hasil pengujian Discriminant Validity dengan Average Variance Extracted (AVE)

\begin{tabular}{|l|c|c|c|c|c|}
\hline \multirow{2}{*}{ Variabel } & \multirow{2}{*}{$\begin{array}{c}\text { Nilai } \\
\text { AVE }\end{array}$} & \multirow{2}{*}{ Akar AVE } & \multicolumn{3}{|c|}{ Skor korelasi antar variabel } \\
\cline { 4 - 6 } & AV1 & X1 & X2 \\
\hline Motivasi Kerja (X1) & 0,674 & $\mathbf{0 , 8 2 1}$ & $\mathbf{0 , 8 2 1}$ & 0,683 & 0,686 \\
\hline Kompetensi (X2) & 0,593 & $\mathbf{0 , 7 7 0}$ & 0,000 & $\mathbf{0 , 7 7 0}$ & 0,680 \\
\hline Kinerja Karyawan (Y) & 0,642 & $\mathbf{0 , 8 0 1}$ & 0,000 & 0,000 & $\mathbf{0 , 8 0 1}$ \\
\hline
\end{tabular}

Sumber : data primer diolah, 2020

Tabel 5. Hasil Uji Composite Reliability 


\begin{tabular}{|l|c|c|}
\hline \multicolumn{1}{|c|}{ Variabel } & Composite Reliability & Kesimpulan \\
\hline Motivasi Kerja (X1) & 0,802 & Reliabel \\
\hline Kompetensi (X2) & 0,813 & Reliabel \\
\hline Kinerja Karyawan (Y) & 0,876 & Reliabel \\
\hline
\end{tabular}

Sumber : data primer diolah, 2020

Tabel 6. Hasil Outer Loading pada PLS-Bootstrapping

\begin{tabular}{|c|l|c|c|}
\hline Variabel & \multicolumn{1}{|c|}{ Indikator } & $\begin{array}{c}\text { Outer } \\
\text { Loadings }\end{array}$ & $\begin{array}{c}\text { Nilai } \\
\text { t-statistik }\end{array}$ \\
\hline \multirow{2}{*}{$\begin{array}{c}\text { Motivasi Kerja } \\
(X 1)\end{array}$} & Kebutuhan Fisiologis (X1.1) & 0,692 & 3,017 \\
\cline { 2 - 4 } & Kebutuhan sosial/merasa memiliki (X1.3) & 0,933 & 25,460 \\
\hline \multirow{2}{*}{$\begin{array}{c}\text { Kompetensi } \\
(X 2)\end{array}$} & Pengetahuan (X2.1) & 0,729 & 3,720 \\
\cline { 2 - 4 } & Keterampilan (X2.2) & 0,839 & 10,740 \\
\cline { 2 - 4 } & Perilaku (X2.3) & 0,737 & 6,969 \\
\hline \multirow{2}{*}{$\begin{array}{c}\text { Kinerja } \\
\text { Karyawan (Y) }\end{array}$} & Kualitatif (seberapa baik) (Y1.1) & 0,781 & 6,021 \\
\cline { 2 - 4 } & Ketepatan waktu menyelesaikan tugas (Y1.2) & 0,880 & 15,072 \\
\cline { 2 - 4 } & Efektivitas penggunaan sumber organisasi (Y1.3) & 0,873 & 20,043 \\
\cline { 2 - 4 } & Cara melakukan pekerjaan (Y1.4) & 0,649 & 4,231 \\
\hline
\end{tabular}

Sumber : data primer yang diolah, 2020

\section{Uji Reliabilitas (Composite Reliability)}

Pengujian Composite Reliability bertujuan untuk menguji reliabilitas konstruk dalam suatu model penelitian secara spesifik untuk indikator reflektif. Reliabilitas adalah sebagai sekumpulan konstruk/variabel laten yang konsisten dengan pengukuran (Hair et al. 2006). Pengukuran yang mempunyai tingkat reliabilitas yang tinggi berarti akan memberikan hasil ukur yang terpercaya. Kriteria untuk menentukan tingkat reliabilitas suatu construc reliability dalam PLS didasarkan pada nilai composite reliability, di mana apabila nilai Composite Reliability dari suatu variabel lebih besar dari 0,7 , maka dapat dinyatakan reliabel.

Berdasarkan Tabel 5 tersebut menunjukkan nilai Composite Reliability untuk masing-masing variabel laten yaitu motivasi kerja (X1), kompetensi (X2) dan kinerja karyawan (Y) adalah lebih besar dari 0,7 (nilai Composite Reliability $>0,7$ ). Dengan demikian, dapat disimpulkan bahwa seluruh alat ukur adalah reliabel. Artinya Construct reliability alat ukur terpenuhi, dan dapat digunakan untuk analisis lebih lanjut.

\section{Permodelan Persamaan Struktural}

Pendekatan Partial Least Square (PLS)

Model Persamaan Struktural Pendekatan Partial Least Square (PLS) terlebih dahulu dilakukan pengujian atau analisis model empirik penelitian. Model yang digunakan adalah First Order Refleksif dan Second Order Refleksif

\section{Model Struktural}

Pengujian terhadap model struktural dilakukan dengan melihat nilai R-Square yang merupakan uji goodnessfit model. Model pengaruh Motivasi Kerja dan Kompetensi terhadap Kinerja Karyawan Yayasan Bina Insan Nusantara Barito di Buntok, Provinsi Kalimantan Tengah sebesar 0,554 dengan t-statistik sebesar 4,798 signifikan ( $\mathrm{t}$-tabel signifikan $5 \%=$ 1,96) oleh karena itu nilai t-statistik lebih besar dari nilai $\mathrm{t}$ tabel 1,96 dan data signifikan.

\section{Outer Loading pada PLS-Bootstrapping}

Analisis outer loading digunakan untuk mengidentifikasi ukuran dan menentukan 
faktor penting atau dominan dalam merefleksikan sebuah faktor dalam membentuk variabel laten. Indikator-indikator dikatakan signifikan dalam mengukur atau membentuk variabel laten (konstruk) apabila nilai t hitung (critical ratio) lebih besar dari $t$ tabel $(1,96)$ atau nilai outer loading lebih besar dari 0,50 dengan tingkat signifikan lebih kecil dari 0,05 . Hasil nilai outer loading indikatorindikator variabel laten dalam penelitian ini akan ditunjukkan pada tabel 6 .

\section{Analisis Deskriptif}

Variabel Motivasi Kerja (X1)

Berdasarkan Tabel 6 di atas hasil outer loading pada PLS- Bootstrapping, indikator dari variabel Motivasi Kerja (X1) menunjukkan bahwa dua indikator tersebut signifikan merefleksikan variabel Motivasi Kerja (X1). Namun yang paling kuat atau dominan dalam membentuk variabel Motivasi Kerja (X1) adalah indikator Kebutuhan sosial/merasa memiliki (X1.3) sebesar 0,933.

\section{Variabel Kompetensi (X2)}

Berdasarkan Tabel 6 di atas hasil outer loading pada PLS- Bootstrapping, indikator dari variabel Kompetensi (X2) menunjukkan bahwa tiga indikator tersebut signifikan merefleksikan variabel Kompetensi (X2). Namun yang paling kuat atau dominan dalam membentuk variabel Kompetensi (X2) adalah indikator Keterampilan (X2.2) yaitu sebesar 0,839 .

\section{Variabel Kinerja Karyawan (Y)}

Berdasarkan Tabel 6 di atas hasil outer loading pada PLS- Bootstrapping, indikator dari variabel Kinerja Karyawan (Y) menunjukkan bahwa empat indikator tersebut signifikan merefleksikan variabel Kinerja Karyawan (Y). Namun yang paling kuat atau dominan dalam membentuk variabel Kinerja Karyaran (Y) adalah Ketepatan waktu menyelesaikan tugas (Y1.2) yaitu sebesar 0,880 .

\section{Hasil Pengujian Hipotesis}

Pengujian hipotesis dilakukan dengan uji $t$ (t-test) pada masing-masing jalur pengaruh langsung secara parsial. Hasil analisis secara lengkap, selanjutnya dapat dilihat pada koefisien jalur sebagaimana Tabel 7.

Tabel 7. Hasil Pengujian Hipotesis (Outer Weights)

\begin{tabular}{|c|c|c|c|c|c|}
\hline Variabel & $\begin{array}{c}\text { Original } \\
\text { sample }\end{array}$ & $\begin{array}{c}\text { Sample } \\
\text { mean }\end{array}$ & $\begin{array}{c}\text { Standard } \\
\text { Error }\end{array}$ & T-Statistic & Ket \\
\hline X1.1 $\leftarrow$ Motivasi Kerja (X1) & 0,391 & 0,374 & 0,144 & 2,714 & Signifikan \\
\hline $\mathrm{X} 1.3 \leftarrow$ Motivasi Kerja $(\mathrm{X} 1)$ & 0,782 & 0,772 & 0,128 & 6,092 & Signifikan \\
\hline $\mathrm{X} 2.1 \leftarrow$ Kompetensi $(\mathrm{X} 2)$ & 0,347 & 0,308 & 0,118 & 2,928 & Signifikan \\
\hline X2.2 $\leftarrow$ Kompetensi (X2) & 0,509 & 0,518 & 0,128 & 3,964 & Signifikan \\
\hline $\mathrm{X} 2.3 \leftarrow$ Kompetensi (X2) & 0,435 & 0,445 & 0,107 & 4,049 & Signifikan \\
\hline $\mathrm{Y} 1 \leftarrow$ Kinerja Karyawan $(\mathrm{Y} 1)$ & 0,259 & 0,247 & 0,059 & 4,420 & Signifikan \\
\hline $\mathrm{Y} 2 \leftarrow$ Kinerja Karyawan (Y1) & 0,336 & 0,341 & 0,054 & 6,228 & Signifikan \\
\hline Y3 $\leftarrow$ Kinerja Karyawan (Y1) & 0,359 & 0,363 & 0,060 & 6,000 & Signifikan \\
\hline $\mathrm{Y} 4 \leftarrow$ Kinerja Karyawan $(\mathrm{Y} 1)$ & 0,291 & 0,291 & 0,080 & 3,639 & Signifikan \\
\hline
\end{tabular}

Sumber : data primer diolah, 2020 


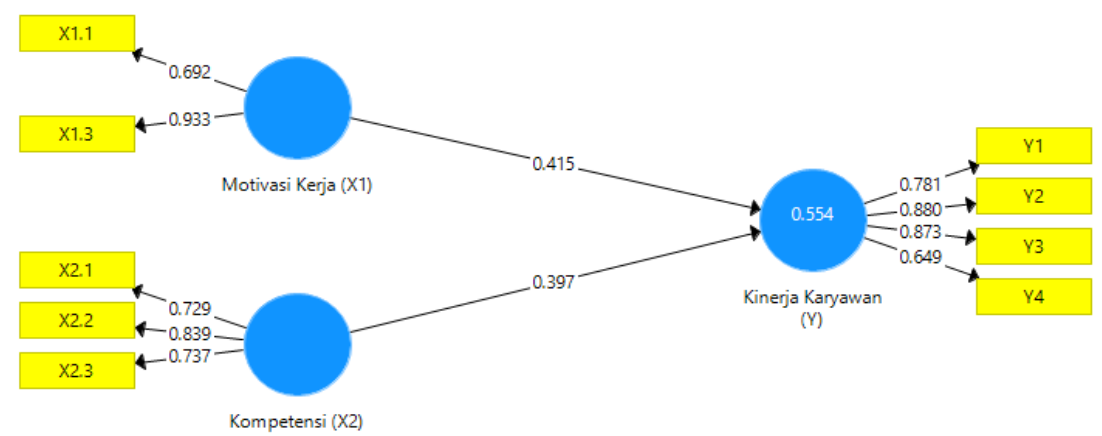

Gambar 2. Diagram Jalur Hasil Pengujian Hipotesis

Sumber : data primer diolah, 2020

Berdasarkan Tabel 7 tersebut hasil pengujian hipotesis terhadap semua variabel penelitian secara bersamaan menunjukkan bahwa tiga jalur hubungan langsung adalah berpengaruh signifikan karena nilai t-statistik lebih besar dari nilai t-tabel $(1,96)$ yaitu variabel motivasi kerja (X1) pada indikator X1.1 sebesar 2,714 dan pada indikator X1.3 sebesar 6,092. Sedangkan pada variabel kompetensi (X2) yaitu pada indikator X2.1 sebesar 2,928, X2.2 sebesar 3,964 dan X2.3 sebesar 4,049. Dan pada variabel Kinerja Karyawan yaitu pada indikator Y1 sebesar 4,420, Y2 sebesar 6,228, Y3 sebesar 6,000 dan Y4 sebesar 3,639.

Hasil pengujian hipotesis pengaruh antar variabel penelitian selain ditunjukkan dari nilai koefisien jalur dan nilai t-statistik sebagaimana Tabel 12, namun dapat pula dilihat dalam bentuk Gambar 2 diagram jalur berikut ini :

Pengujian Hipotesis 1, Motivasi Kerja (XI)

berpengaruh terhadap Kinerja Karyawan (Y)

Pengujian hipotesis 1 (H1) dengan menggunakan Path Coefficens menunjukkan bahwa terdapat pengaruh positif variabel Motivasi Kerja (X1) terhadap Kinerja Karyawan (Y). Hal ini diperoleh dari nilai orginal sample sebesar 0,415 dengan nilai tstatistik 2,966 nilai tersebut lebih besar dari nilai t-tabel $(1,96)$. Hasil ini membuktikan bahwa Motivasi Kerja berpengaruh signifikan terhadap Kinerja Karyawan.

\section{Pengujian Hipotesis 2, Kompetensi (X2) terhadap Kinerja Karyawan (Y)}

Pengujian hipotesis 2 (H2) dengan menggunakan Path Coefficens menunjukkan bahwa terdapat pengaruh positif variabel Kompetensi (X2) terhadap Kinerja Karyawan (Y). Hal ini diperoleh dari nilai orginal sample sebesar 0,397 dengan nilai tstatistik 2,523 nilai tersebut lebih besar dari nilai t-tabel $(1,96)$. Hasil ini membuktikan bahwa Kompetensi berpengaruh signifikan terhadap Kinerja Karyawan.

\section{Pembahasan}

Sumber Daya Manusia merupakan hal yang paling penting dalam organisasi privat maupun publik, semakin baik kemampuan pegawai, maka semakin baik pula kinerja dalam organisasi. Sebaliknya semakin rendah kemampuan pegawai, maka semakin rendah pula kinerja organisasi. Agar aktifitas manajemen berjalan dengan baik, organisasi harus memiliki pegawai yang berkompeten atau berkemampuan tinggi untuk mengelola organisasi seoptimal mungkin sehingga kinerja pegawai meningkat. Manusia selalu berperan aktif dalam setiap organisasi karena manusia menjadi perencana, pelaku dan penentu terwujudnya tujuan organisasi. Tujuan tidak mungkin terwujud tanpa peran 
aktif pegawai meski peralatan yang dimiliki oleh organisasi begitu canggihnya. Fokus kajian manajemen sumber daya manusia adalah masalah tenaga kerja yang diatur dalam urutan fungsi-fungsinya, agar efektif dan efisien dalam mewujudkan tujuan organisasi, pegawai dan masyarakat.

Organisasi dapat berkembang luas dengan segala kegiatan-kegiatan yang dilakukan untuk mencapai tujuan yang diinginkan dengan menggunakan sumber daya manusia yang telah tersedia, tetapi untuk mencapai tujuan tersebut, tidak cukup hanya dengan jalan memperoleh pegawai yang dianggap paling kompeten, akan tetapi tidak kalah pentingnya dengan secara terus menerus pimpinan memberikan motivasi dan meningkatkan disiplin serta kompetensi pegawainya agar dapat mencapai kinerja terbaiknya dalam mencapai efektifitas kerja dalam menjalankan tugastugasnya di organisasi.

Kinerja Pegawai adalah sebagai hasil kerja yang dicapai oleh individu yang disesuaikan dengan peran atau tugas individu tersebut dalam suatu organisasi dalam periode tertentu, yang dihubungkan dengan suatu ukuran nilai atau standar tertentu dari organisasi di mana individu tersebut bekerja. Kinerja yang baik akan tercapai apabila faktor-faktor yang menyebabkan terjadinya kinerja tersebut tercukupi dengan baik. Beberapa faktor yang mempengaruhi kinerja pegawai diantaranya motivasi dan kompetensi

\section{Hasil penelitian terhadap variabel motivasi} kerja (XI)

Dari hasil distribusi frekuensi serta hasil uji validitas dan uji pengaruh diatas dapat terlihat jelas bahwa ada dua indikator dan dua item pertanyaan pada motivasi kerja yang masih lemah. Untuk itu peneliti melakukan wawancara pada beberapa guru secara acak guna mengetahui apa penyebab lemahnya dua indikator dan dua item pertanyaan tersebut. Sekaligus ingin mengetahui apa harapan dan keinginan dari guru-guru pendidik pada Yayasan Insan Bina Nusantara Barito.

Pada Indikator yang masih lemah X1.2 Kebutuhan rasa aman, dan pada item pertanyaan X1.2.1 Yayasan dapat memberikan kenyaman kerja pada setiap guru, diperoleh jawaban hasil wawancara yaitu sebagai berikut : guru-guru dituntut harus disiplin yang tinggi. Dan harus menjalankan 5S (senyum, salam, sapa, sopan, santun), hal ini diharapkan agar peserta didik mengikuti kebiasaan baik tersebut. Jam kerja dimulai pukul 06.15 wib hal ini dikarenakan guru-guru harus standby di depan pagar untuk menyambut anak-anak datang dengan menjalankan 5S diatas. Selesai jam kerja pukul 12.00 wib. Jika melakukan pekerjaan tambahan (TPA) hingga pukul 14.00 wib akan mendapatkan insetif tambahan sebesar Rp.100.000,-, dan kalau bekerja sampai pukul 16.00 wib akan mendapatkan insentif tambahan sebesar Rp.100.000,- lagi. Jika tidak hadir, maka insentif akan dipotong sebesar Rp.15.000,-/hari. Kecuali jika ada surat keterangan dari dokter yang menyatakan sakit dan harus istirahat, atau sedang melaksanakan perjalanan dinas, maka tidak akan mendapatkan potongan.

Pada Indikator yang masih lemah X1.4 Kebutuhan akan harga diri, dan pada item pertanyaan X1.4.1 Yayasan telah memberikan penghargaan kepada guru yang memiliki loyalitas dan etos kerja yang tinggi, diperoleh jawaban hasil wawancara yaitu sebagai berikut : Guru-guru masih belum merasakan dampak dari nilai atas penghargaan terhadap loyalitas dan etos kerja. Harapan mereka, agar kesejahteraan lebih ditingkatkan lagi, sehingga guru-guru merasa lebih bersemangat dan termotivasi untuk mewujudkan tujuan Yayasan Insan Bina Nusantara Barito.

Hasil penelitian terhadap variabel kompetensi $(X 2)$ 
Selanjutnya hasil penelitian terhadap variabel kompetensi, terdapat satu indikator dan satu item pertanyaan pada variabel Kompetensi, yang masih lemah pada jawaban responden.

Pada Indikator yang masih lemah X2.4 Pengalaman, dan pada item pertanyaan X2.4.1 Menerapkan ilmu yang diperoleh ketika mengikuti pelatihan, guna kemajuan yayasan, diperoleh jawaban hasil wawancara yaitu sebagai berikut : hanya beberapa guruguru saja yang mengikuti pelatihan, dan hanya orang-orang itu saja yang pergi pelatihan, sehingga kurang adanya pemerataan dalam hal mendapatkan ilmu dan pengalaman. Hendaknya guru-guru yang mengikuti pelatihan dapat menyampaikan informasi/ilmu yang didapatnya kepada guru-guru yang tidak berkesempatan mendapatkan pelatihan. Sehingga guru-guru yang tidak mengikuti pelatian mendapatkan informasi terbaru mengenai perkembangan yang terjadi.

\section{Hasil penelitian terhadap variabel kinerja} karyawan (Y)

Selanjutnya adalah Variabel Kinerja, semua indikator dan item pertanyaan signifikan dan bernilai positif.

Dari hasil analisis uji validitas diatas peneliti merasa tertarik karena sangat jarang ketika motivasinya masih ada yang lemah biasanya kinerjanya juga rendah, begitu pula ketika kompetensinya masih ada yang lemah biasanya kinerjanya juga rendah. Berbeda pada kasus yang peneliti temukan di Yayasan Bina Insan Nusantara Barito. Dengan motivasi dan kompetensi yang masih lemah, guru-guru memberikan kinerja yang maksimal. Untuk itu peneliti melakukan wawancara kembali kepada guru-guru yang belum pernah peneliti wawancara guna mendapatkan informasi yang lebih mendalam lagi. Dari hasil wawancara tambahan peneliti mendapatkan informasi yaitu :

1) Guru-guru merasa mencintai pekerjaanya dan mencintai dunia anak

2) Kedekatan guru satu sama lain, merasa sudah seperti keluarga. Guru senior membimbing guru yang masih baru (junior), dan menegur dengan baik jika terdapat kesalahan (tidak dibiarkan)

3) Disiplin kerja yang tinggi

4) Ingin mendapatkan stutus sosial (karena mayoritas berawal dari ibu rumah tangga)

5) Mendapatkan insentif tambahan dari Dinas Pendidikan Nasional, selain insentif dari yayasan

6) Berkerja di sekolah yang sangat bonafit, sehingga mengangkat stutus sosial di masyarakat

7) Berlomba-lomba bekerja maksimal untuk mendapatkan sertifikasi guru, karena baru 1 orang (kepala sekolah) yang mendapatkan sertifikasi guru.

Hasil wawancara dengan Ketua Yayasan Bina Insan Nusantara Barito

Setelah mengetahui jawaban dari guruguru. Selanjutnya peneliti melakukan konfirmasi secara langsung kepada Ketua Yayasan Ibu Isnah Cholisoh, M.Pd untuk menggali informasi dan mencari tau informasi yang masih bias (kurang jelas), sehingga tidak menimbulkan kesalah fahaman.

Dari variabel motivasi kerja terutama pada indikator yang masih lemah, yaitu indikator X1.2 dan X1.4. Berikut ini adalah hasil konfirmasi peneliti secara langsung kepada Ketua Yayasan Bina Insan Nusantara Barito :

1) Penghasilan guru-guru bersumber dari yayasan, dengan melihat Kinerja guruguru dengan acuan sesuai dengan DUKY (Daftar Urutan Kepegawaian Yayasan). 
2) Selain gaji sebagai guru, yayasan juga memberikan tunjangan jabatan yang diberikan sesuai kinerja tanpa melihat DUKY sehingga guru-guru berlombalomba menunjukan kreatifitas dan kinerjanya untuk menempati posisi, seperti : wali kelas, koordinator TK A, koordinator TK B, koordinator kegiatan ekstra kurikuler (tari kreasi, kesenian daerah dan marcing band), koordinator kegiatan keagamaan, dll.

3) Semua guru diuruskan oleh yayasan untuk mendapatkan honor Dinas Pendidikan Nasional, yang mana terbukti semua karyawan mendapatkan honor dari dinas. Honor secara bertahap dari Rp.250.000,- s/d Rp.700.000,--

4) Pada saat perayaan Hari Raya Idul Fithri dan Natal, yayasan memberikan perhatian dengan memberikan sembako kepada guru-guru.

5) Guru yang memasukkan sekolahnya akan bebas uang gedung senilai Rp.750.000.

6) Guru-guru difasilitasi sarana belajar yang berupa APE (alat peraga edukatif) dan kelas yang ber-ac agar merasa nyaman dalam bekerja.

7) Yayasan menyadari pemberian gaji masih dibawah Upah Minimum Regional, dan yayasan pun mengharapakan gaji yang lebih memadai, akan tetapi saat ini hanya segitulah kemampuan yayasan karena yayasan yang saat ini selalu sedang membangun gedung dll secara bertahap, dan penambahan fasilitas merupakan murni dari dana Yayasan bukan dari dana Pemerintah Daerah.

8) Yayasan memberikan penghargaan berupa beasiswa kepada guru-guru yang memiliki kreatifitas dan kinerja yang baik untuk melanjutkan pendidikan ke S1 pada Universitas Terbuka (UT) sebanyak 5 orang guru.
Dari variabel kompetensi terutama pada indikator yang masih lemah, yaitu indikator $\mathrm{X} 2.4$. Berikut ini adalah hasil konfirmasi peneliti secara langsung kepada Ketua Yayasan Bina Insan Nusantara Barito, yaitu sebagai berikut :

1) Training 3 bulan dengan gaji Rp. 400.000,- ribu setelah training guru akan mendapatkan gaji sebesar Rp.450.000,-

2) Untuk guru baru, peningkatan kompetensi secara otomatis akan di ajarkan di kelas. Jadi guru baru, akan dilebur ke berbagai kelas, sehingga guru baru secara alami belajar langsung dari seniornya.

3) Setiap libur semester akan diadakan IHT (In House Training), yang mana dalam kegiatan IHT guru-guru akan dibekali berupa penyampaian kurikulum, pembuatan program, pembuatan Silabus dan RPP baik rencana program kerja secara harian, mingguan hingga program kerja semester. Adapun pelaksanaan dilakukan di gedung Yayasan dan lama kegiatan dilakukan selama 1 minggu.

4) Untuk kegiatan pelatihan atau lombalomba, guru-guru selalu mendapatkan bantuan transportasi dan akomodasi yang besarnya sesuai dengan kegiatan dan sisa dana tidak diminta kembali oleh yayasan, jika kurang akan diberikan dana tambahan. Dan semua biaya ditanggung $100 \%$ oleh Yayasan.

Untuk variabel kinerja karyawan, semua indikator dan item telah memenuhi kreteria signifikan. Namun harapan dari ketua yayasan adalah sebagai berikut :

1) Untuk menumbuhkan profesional guru sekolah telah menyediaakan alat permainan edukatif (APE) yang dibeli sesuai keperluan setiap kelas, karena menggunakan sistem sentra, maka semua sentra dibelikan. Akan tetapi jumlahnya 
masih belum sesuai jumlah anak. Dengan harapan guru memiliki motivasi untuk berinovasi dan kreatif dalam pembuatan APE yang dibuat sendiri disesuaikan keperluan. Karena hal ini yayasan tau bahwa guru-guru memang diarahkan untuk kreatif dan trampil membuat APE, sehingga memiliki kompetensi yang lebih. Apabila guru yang tidak kreatif dan inovatif itu bisa dikatakan guru yang kurang kinerjanya. Teknis sudah diberikan dalam sosialisasi baik guru dan orang tua (parenting class) yang mana pencapaian pembelajaran disemua line juga tergantung pada proses belajar mengajar yang mana APE juga mencapai tujuan itu.

2) Guru-guru harus lebih sabar, bijaksana, ulet, rendah hati, beriman, dan berakhlak mulia, dapat menjalankan berbagai peraturan atau budaya baik yang dijalankan di Yayasan.

Bagi guru-guru yang tidak mematuhi aturan yang telah ditetapkan akan diberikan pembinaan. Guru-guru yang tidak dapat sejalan dengan peraturan yayasan akan mendapatkan SP 1, SP 2, bahkan SP3. Sebagai contoh pernah ada guru yang di scorsing (tidak boleh mengajar), bahkan sampai penurunan gaji. Jika tidak bisa dilakukan pembinaan, memberikan motivasi, hingga evaluasi, dengan terpaksa yayasan akan melakukan pemutusan hubungan kerja (PHK).

\section{KESIMPULAN DAN SARAN}

\section{Kesimpulan}

Pengujian hipotesis 1 (H1) dengan menggunakan Path Coefficens menunjukkan bahwa terdapat pengaruh positif variabel Motivasi Kerja (X1) terhadap Kinerja Karyawan (Y). Hal ini diperoleh dari nilai orginal sample sebesar 0,415 dengan nilai tstatistik 2,966 nilai tersebut lebih besar dari nilai t-tabel $(1,96)$. Hasil ini membuktikan bahwa Motivasi Kerja secara parsial berpengaruh positif dan signifikan terhadap Kinerja Karyawan.

Pengujian hipotesis 2 (H2) dengan menggunakan Path Coefficens menunjukkan bahwa terdapat pengaruh positif variabel Kompetensi (X2) terhadap Kinerja Karyawan (Y). Hal ini diperoleh dari nilai orginal sample sebesar 0,397 dengan nilai t-statistik 2,523 nilai tersebut lebih besar dari nilai ttabel $(1,96)$. Hasil ini membuktikan bahwa Kompetensi berpengaruh positif dan signifikan terhadap Kinerja Karyawan.

Dengan demikian terjawab hipotesis dari penelitian Pengaruh Motivasi Kerja dan Kompetensi terhadap Kinerja Karyawan Yayasan Bina Insan Nusantara Barito di Buntok, Provinsi Kalimantan Tengah.

\section{Saran}

Berdasarkan pembahasan dan kesimpulan yang telah diuraikan diatas, ada beberapa hal saran/masukan dari penulis yaitu sebagai berikut : hasil dari penelitian ini diharapkan mampu memberikan kontribusi kepada pihak Yayasan, dan pihak yayasan hendaknya terbuka kepada guru-guru mengenai kondisi keuangan Yayasan. Karena pada saat ini yayasan terus membangun gedung dan penambahan fasilitas guna menunjang sarana belajar mengajar. Semangat dari kinerja guruguru di yayasan agar terus dipertahankan, mengingat sangat susah mencari guru-guru yang memiliki dedikasi dan loyalitas kerja yang tinggi. Penelitian ini juga memiliki keterbatasan seperti jumlah sampel yang terbatas dan masih terdapat instrument yang mungkin memiliki tingkat yang lebih baik dalam mengukur motivasi kerja, kompetensi dan kinerja Karyawan Yayasan Bina Insan Nusantara di Buntok.

\section{DAFTAR PUSTAKA}

Anatan Lina \& Ellitan Lena. (2007).

Manajemen Sumber Daya Manusia 
dalam Bisnis Modern. Bandung : Alfabeta.

Aprimulki Endah. (2017). Pengaruh Konflik Peran, Kelebihan Peran, Independensi, dan Kompetensi Terhadap Kinerja Auditor Dengan Kecerdasan Spiritual sebagai Variabel Moderasi. Pekanbaru \& Padang : Jurnal Penelitian.

Basuki. (2013). Disertasi. Knowledge Management dan Kualitas Pelayanan Dalam Memediasi Pengaruh Praktik Manajemen Sumberdaya Manusia Strategik terhadap Kinerja Organisasi (Studi pada Rumah Sakit Pemerintah dan Swasta di Kalimantan Selatan). Malang : Universitas Brawijaya

Fahmi Irham. (2015). Manajemen Sumber Daya Manusia. Bandung : Alfabeta

Ghozali Imam. (2006). Metode Alternatif dengan Partial Least Squares (PLS). Semarang : Universitas Diponegoro Semarang

Ghozali Imam. (2017). Pengaruh Motivasi Kerja, Kepuasan Kerja dan Kemampuan Kerja Terhadap Kinerja Pegawai pada Kantor Kementerian Agama Kabupaten Banjar. Martapura : Jurnal Penelitian

Hamali Yusuf Arif. (2018). Pemahaman

Manajemen Sumber Daya Manusia, Strategi Mengelola Karyawan. Yogyakarta : CAPS.

Handoko Hani T. (1987). Manajemen Personalia dan Sumberdaya Manusia. Yogyakarta : BPFE.

Hussein Sabil Ananda. (2015). Modul Ajar Penelitian Bisnis dan Manajemen Menggunakan Partial Least Squares (PLS) dengan smartPLS 3.0. Malang : Universitas Brawijaya
Mangkunegara Prabu Anwar A. A. (2001). Manajemen Sumber Daya Manusia Perusahaan. Bandung : PT. Remaja Rosdakarya.

Mangkuprawira Sjafri. (2011). Manajemen Sumber Daya Manusia Strategik. Bogor: Ghalia Indonesia.

Marwansyah. (2009). Manajemen Sumber Daya Manusia. Bandung : Alfabeta.

Oei Istijanto. (2010). Riset Sumber Daya Manusia. Jakarta : PT. Gramedia Pustaka Utama.

Rahayuningsih Sri dan Maelani Nonik. (2018). Pengaruh Kompetensi, Kompensasi dan Motivasi terhadap Kinerja Karyawan (Studi Pada PT. Pisma Garment Demak Jawa Tengah). Semarang: Jurnal Penelitian

Sugiyono. (1999). Metodologi Penelitian. Bandung : Alfabeta.

Siswanto H.B. (2005). Pengantar Manajemen. Bandung : Bumi Aksara.

Sujarweni Wiratna V. (2010). Metodologi Penelitian Bisnis dan Ekonomi. Bandung : Alfabeta.

Sukmawati Dally. (2017). Pengaruh Motivasi, Disiplin, dan Kompetensi terhadap Kinerja Pegawai. Garut : Jurnal Penelitian.

Wijaya Tanto dan Andreani Fransisca. (2015). Pengaruh Motivasi Dan Kompensasi Terhadap Kinerja Karyawan Pada PT Sinar Jaya Abadi Bersama. Surabaya : Jurnal Penelitian

Wirawan. (2008). Evaluasi Kinerja Sumber Daya Manusia. Jakarta : Salemba Empat. 